\title{
TAOK3 Gene
}

National Cancer Institute

\section{Source}

National Cancer Institute. TAOK3 Gene. NCI Thesaurus. Code C106218.

This gene is involved in both protein phosphorylation and signal transduction. 